\title{
Therapeutic implications of cancer gene amplifications without mRNA overexpression: silence may not be golden
}

\author{
Amélie Boichard ${ }^{1 *}$, Scott M. Lippman ${ }^{2}$ and Razelle Kurzrock ${ }^{2,3}$
}

\begin{abstract}
Amplifications of oncogenic genes are often considered actionable. However, not all patients respond. Questions have therefore arisen regarding the degree to which amplifications, especially non-focal ones, mediate overexpression. We found that a subset of high-level gene amplifications ( $\geq 6$ copies) (from The Cancer Genome Atlas database) was not over-expressed at the RNA level. Unexpectedly, focal amplifications were more frequently silenced than non-focal amplifications. Most non-focal amplifications were not silenced; therefore, non-focal amplifications, if over-expressed, may be therapeutically tractable. Furthermore, specific silencing of high-level focal or non-focal gene amplifications may explain resistance to drugs that target the relevant gene product.
\end{abstract}

Keywords: Gene amplification, mRNA expression, Therapeutic actionability

\section{To the Editor,}

Targeted therapy resistance affects a subset of cancer patients [1,2]. Indeed, $\sim 13 \%$ of somatic mutations are not expressed at the RNA level [3]. Little is known regarding gene amplifications. We examined The Cancer Genome Atlas (TCGA) to determine RNA expression of highlevel amplifications, including in cancer-related genes. We observed that a minority of high-level amplifications are silenced. Silencing is, unexpectedly, more frequent in focal than non-focal amplifications. However, most focal and non-focal amplifications are over-expressed. Therefore, our observations suggest important points, which require further clinical validation: (1) high-level amplifications can be silenced and therefore may not be amenable to therapeutic targeting: and (2) non-focal amplifications are sometimes not considered druggable; however, they are frequently overexpressed, suggesting that they could be pharmacologically tractable.

\footnotetext{
*Correspondence: amelie.boichard@chru-strasbourg.fr

1 Department of Molecular Cancer Genetics, University of Strasbourg Hospitals, 67000 Strasbourg, France
}

Full list of author information is available at the end of the article
Data from 675 TCGA samples (23 tumor types) with differential RNA expression was retrieved (Additional file 1: Methods ; Additional file 2: Table S1). A total of 166,707 amplifications were reviewed; there was an average of 304 [268-340] (mean [95\% confidence interval (CI)]) high-level amplifications ( $\geq 6$ copies) per sample. Amplifications were categorized as "non-focal" when $\geq 1$ other amplification was observed within a 0.1 megabase $(\mathrm{Mb})$ genomic window. Non-focal amplifications result from large genome rearrangements encompassing $>1$ gene. Using the aforementioned threshold, 137,819 (83\%) amplifications were considered non-focal; $28,888(17 \%)$ amplifications, focal; respectively, 5612 non-focal (68\%) and 2599 focal (32\%) amplifications in cancer-related genes (Table 1).

High-level amplifications correlated with a+548 [+500 to +595$] \%$ (mean, 95\% CI) increase of expression for the corresponding mRNA in the tumor compared to the adjacent tissue. When considering only cancerrelated genes, the overall expression increase was +1084 $[+742$ to +1426$] \%$ (mean, 95\% CI). There was no original author(s) and the source, provide a link to the Creative Commons licence, and indicate if changes were made. The images or other third party material in this article are included in the article's Creative Commons licence, unless indicated otherwise in a credit line to the material. If material is not included in the article's Creative Commons licence and your intended use is not permitted by statutory regulation or exceeds the permitted use, you will need to obtain permission directly from the copyright holder. To view a copy of this licence, visit http://creativecommons.org/licenses/by/4.0/. The Creative Commons Public Domain Dedication waiver (http://creativeco mmons.org/publicdomain/zero/1.0/) applies to the data made available in this article, unless otherwise stated in a credit line to the data. 
Table 1 Silencing distribution between focal and non-focal high-level amplifications (data from TCGA)

\begin{tabular}{|c|c|c|c|c|c|c|}
\hline & \multirow{2}{*}{$\begin{array}{l}\text { Total number } \\
\text { of high-level } \\
\text { amplifications* } \\
N(\%)\end{array}$} & \multicolumn{2}{|c|}{$\begin{array}{l}\text { Tumor-to-normal differential RNA } \\
\text { expression }\end{array}$} & \multirow{2}{*}{$\begin{array}{l}\text { Number of } \\
\text { silenced }{ }^{* *} \\
\text { amplifications } \\
N(\%)\end{array}$} & \multirow{2}{*}{$\begin{array}{l}\text { Number of } \\
\text { non-silenced } \\
\text { amplifications } \\
N(\%)\end{array}$} & \multirow[t]{2}{*}{ Chi-square $p$ value } \\
\hline & & $\begin{array}{l}\text { Mean }[95 \% \\
\text { confidence interval] }\end{array}$ & $T$ test $p$ value & & & \\
\hline \multicolumn{7}{|l|}{ All genes $(N=18,870)$} \\
\hline All amplifications & $166,707(100 \%)$ & $\begin{array}{l}+548[+500 \text { to } \\
+595] \%\end{array}$ & - & $9534(6 \%)$ & $157,173(94 \%)$ & - \\
\hline $\begin{array}{l}\text { Focal amplifica- } \\
\text { tions }\end{array}$ & $137,819(83 \%)$ & $\begin{array}{l}+559[+505 \text { to } \\
+613] \%\end{array}$ & 0.296 & $6973(4 \%)$ & $130,846(78 \%)$ & $<0.00001$ \\
\hline $\begin{array}{l}\text { Non-focal amplifi- } \\
\text { cations*** }\end{array}$ & $28,888(17 \%)$ & $\begin{array}{l}+493[+400 \text { to } \\
+585] \%\end{array}$ & & $2561(2 \%)$ & $26,328(16 \%)$ & \\
\hline \multicolumn{7}{|c|}{ Cancer-related genes ${ }^{* * *}(N=832)$} \\
\hline All amplifications & $8211(100 \%)$ & $\begin{array}{l}+1084[+742 \text { to } \\
+1426] \%\end{array}$ & - & $485(6 \%)$ & $7726(94 \%)$ & - \\
\hline $\begin{array}{l}\text { Focal amplifica- } \\
\text { tions }\end{array}$ & $5612(68 \%)$ & $\begin{array}{l}+1207[+723 \text { to } \\
+1691] \%\end{array}$ & 0.300 & $233(3 \%)$ & $5379(66 \%)$ & $<0.00001$ \\
\hline $\begin{array}{l}\text { Non-focal amplifi- } \\
\text { cations }\end{array}$ & $2599(32 \%)$ & $\begin{array}{l}+818[+549 \text { to } \\
+1088] \%\end{array}$ & & $252(3 \%)$ & $2347(29 \%)$ & \\
\hline
\end{tabular}

Numbers in bold represent statistically significant Chi-square p-values at the alpha level of 0.05 , as well as the criteria that have the largest contribution to the Chisquare statistic

*Gene level amplification included those genes with $\geq 6$ copies

**RNA silencing was defined by an $80 \%$ decrease of expression in the tumor sample compared to the normal sample, including only tumor samples that presented a high-level amplification for that gene ( $\geq 6$ copies of the gene)

***Non-focal amplifications are co-amplification of genes that are located in the same 0.1 megabase genomic window

****Cancer-related genes are listed in Additional file 2: Table S2. The list of cancer-related genes was defined as the union of genes curated by the Cancer Gene Census (CGC) from the Catalogue of Somatic Mutations in Cancer (COSMIC) and genes analyzed by Foundation Medicine Inc. in their commercial panels Foundation One and Foundation One Heme ( $N=946$ distinct genes)

difference between the focal and the non-focal groups (Table 1).

A subset of 9534 (6\%) amplifications were silenced (i.e., presenting a decrease of expression $>80 \%$ in the tumor compared to normal adjacent tissue). This proportion was similar when only considering cancer-related genes $(N=485,6 \%)$ (Table 1$)$.

A Chi-square test was performed to examine the relationship between gene silencing and amplification type. Interestingly, gene amplifications were either consistently focal or non-focal. Amongst the 832 amplified cancerrelated genes, 243 were always focally amplified and 589 were uniformly non-focally amplified. Focal amplifications were more likely to be silenced ( $9 \%$ vs $5 \%$ silenced amplifications; odds-ratio (OR) $[95 \% \mathrm{CI}]=1.83[1.74-$ 1.91]; $\left.X^{2}(1, N=166,707)=641.4, p<0.00001\right)$, and this held true when considering only cancer-related genes ( $10 \%$ versus $4 \%$ silenced amplifications; $O R=2.48$ [2.062.98]; $\left.X^{2}(1, N=8211)=98.2, p<0.00001\right) \quad($ Table 1$)$. Interestingly, many cancer-related genes that are druggable/activate druggable pathways were less frequently silenced than cancer-related genes without active therapies (Fig. 1).
The mechanism of amplification silencing was not elucidated. Prior studies suggest potential mechanisms such as epigenetic modifications [4], miRNA regulation [5], and/or factors that influence RNA-decay such as RNAbinding proteins [6].

Overall, our findings indicate that high-level amplifications are prevalent in tumors. Further, as expected, gene copy-number amplifications correlated with an overall increase in mRNA expression. Even so, highlevel amplifications may be associated with genespecific silenced RNA expression. Surprisingly, focal amplifications were more likely to be silenced than non-focal amplifications, and this held true when considering only cancer-related genes. Furthermore, most non-focal amplifications were not silenced, suggesting that such amplifications may still be actionable. Of interest, cancer genes that were more likely to be considered druggable and/or have established prognostic or predictive attributes were usually not silenced, while cancer-related genes that are often considered therapeutically intractable were more often silenced. Since silencing of amplifications would nullify tumorigenic impact, and also lead to resistance (if the gene product was the treatment target), it is conceivable that more 


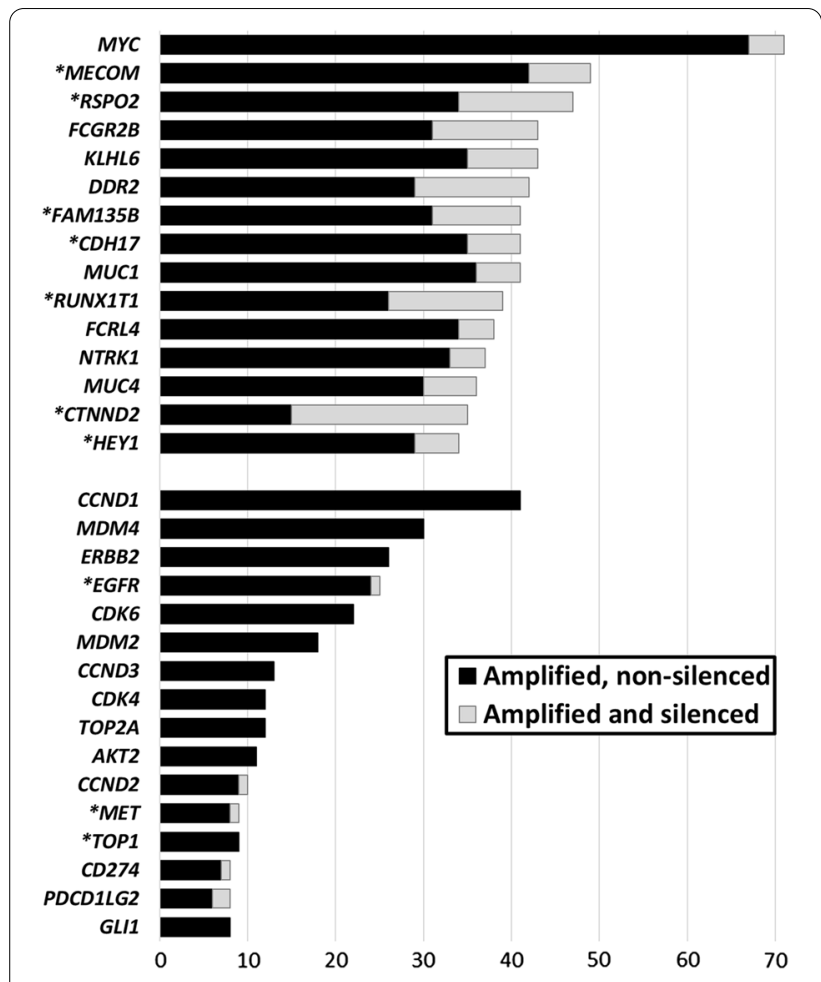

Fig. 1 Frequently silenced cancer-related gene amplifications (TCGA). Top panel: cancer-related genes that are amplified in $\geq 5 \%$ $(N \geq 34)$ of the tumor samples $(N=675)$ and silenced in $\geq 10 \%$ of those cases $(N \geq 4)$. Black = amplified, not silenced; grey= amplified and silenced. Bottom panel (starting with CCND1): sampling of common potentially actionable oncogenes; they are infrequently silenced. *Genes preceded by an asterisk were exclusively found to be focally amplified. Gene level amplification included those genes with $\geq 6$ copies; RNA silencing was defined by $\geq 80 \%$ expression decrease in the tumor sample compared to the normal sample, including only tumor samples that had high-level amplification for that gene ( $\geq 6$ copies of the gene); non-focal amplifications referred to co-amplification of genes located in the same 0.1 megabase genomic window

frequently silenced amplifications would be less likely to be associated with therapeutic or prognostic/predictive impact. These findings echo those previously published in gliomas where the authors suggested that, even when amplified, genes that are normally silent in a given cell type may play no role in tumor progression [7].

In conclusion, our study indicates that the consequences of silencing on response versus resistance after targeted therapies matched to oncogenic amplifications requires in vitro verification and prospective clinical studies. Taken together with the existing literature $[3,8$, 9], we suggest that gene silencing may be an important mechanism of therapeutic resistance, and that optimal pharmacologic intervention in cancer may demand transcriptomic in addition to genomic interrogation and considerations for epigenetic modulation.

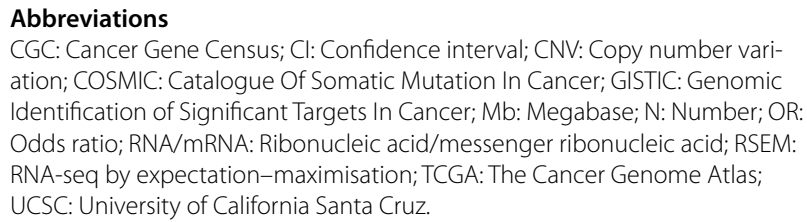
ation; COSMIC: Catalogue Of Somatic Mutation In Cancer; GISTIC: Genomic Identification of Significant Targets In Cancer; Mb: Megabase; N: Number; OR: Odds ratio; RNA/mRNA: Ribonucleic acid/messenger ribonucleic acid; RSEM: RNA-seq by expectation-maximisation; TCGA: The Cancer Genome Atlas; UCSC: University of California Santa Cruz.

\section{Supplementary Information}

The online version contains supplementary material available at https://doi. org/10.1186/s13045-021-01211-1.

Additional file 1. Methods [10-13].

Additional file 2. Supplementary Tables 1 and 2 .

\section{Acknowledgements}

Not applicable.

\section{Authors' contributions}

Study conception and design (AB, RK), data acquisition and analysis (AB), result interpretation ( $A B, S M L, R K)$, manuscript writing and revision ( $A B, S M L, R K)$. All authors read and approved the final manuscript.

\section{Authors' information}

Amelie Boichard, PharmD PhD: Clinical Molecular Geneticist-Department of Molecular Cancer Genetics, University of Strasbourg Hospitals, France (amelie.boichard@chru-strasbourg.fr).

Scott M. Lippman, MD: Distinguished Professor of Medicine and Director of Moores Cancer Center at UC San Diego Health.

Razelle Kurzrock, MD:WIN Consortium for Precision Medicine (teoam2011@ gmail.com).

\section{Funding}

RK was funded in part by the Joan and Irwin Jacobs Fund. RK and SML received funding from NIH P30 CA023100.

Availability of data and materials

The data that support the findings of this study derived from The Cancer Genome Atlas (TCGA) project (https://www.cancer.gov/about-nci/organizati on/ccg/research/structural-genomics/tcga).

\section{Declarations}

Ethics approval and consent to participate Not applicable.

\section{Consent for publication \\ Not applicable.}

\section{Competing interests}

RK receives research funding from Genentech, Merck Serono, Pfizer, Boehringer Ingelheim, TopAlliance, Takeda, Incyte, Debiopharm, Medimmune, Sequenom, Foundation Medicine, Konica Minolta, Grifols, Omniseq, and Guardant, as well as consultant and/or speaker fees and/or advisory board for X-Biotech, Neomed, Pfizer, Actuate Therapeutics, Roche, Turning Point Therapeutics, TD2/Nolastra, Bicara Therapeutics, Inc., has an equity interest in IDbyDNA and CureMatch Inc, serves on the Board of CureMatch and CureMetrix, and is a co-founder of CureMatch. S.M.L. is a co-founder of io9 and member of Biological Dynamics scientific advisory board. 


\section{Author details}

'Department of Molecular Cancer Genetics, University of Strasbourg Hospitals, 67000 Strasbourg, France. ${ }^{2}$ Center for Personalized Cancer Therapy, Moores Cancer Center, University of California, La Jolla, CA 92093, USA. ${ }^{3}$ WIN Consortium, Paris, France.

Received: 1 September 2021 Accepted: 4 November 2021

Published online: 02 December 2021

\section{References}

1. Gerlinger $\mathrm{M}$, et al. Intratumor heterogeneity and branched evolution revealed by multiregion sequencing. N Engl J Med. 2012;366:883-92.

2. Sicklick JK, et al. Molecular profiling of cancer patients enables personalized combination therapy: the I-PREDICT study. Nat Med. 2019;25:744-50.

3. Adashek JJ, et al. Transcriptomic silencing as a potential mechanism of treatment resistance. JCI Insight. 2020;5:e134824.

4. Tycko B. Epigenetic gene silencing in cancer. J Clin Invest. 2000;105:401-7.

5. Huntzinger E, Izaurralde E. Gene silencing by microRNAs: contributions of translational repression and mRNA decay. Nat Rev Genet. 2011;12:99-110.

6. Oliveira C, Faoro H, Alves LR, Goldenberg S. RNA-binding proteins and their role in the regulation of gene expression in Trypanosoma cruzi and Saccharomyces cerevisiae. Genet Mol Biol. 2017;40:22-30.

7. Vogt $\mathrm{N}$, et al. Relationships linking amplification level to gene overexpression in gliomas. PLoS ONE. 2010;5(12):e14249.

8. Rodon J, et al. Genomic and transcriptomic profiling expands precision cancer medicine: the WINTHER trial. Nat Med. 2019;25:751-8.

9. Uhlen $\mathrm{M}$, et al. A pathology atlas of the human cancer transcriptome. Science. 2017:357(eaan2507):1-11.

10. Mermel CH, et al. GISTIC20 facilitates sensitive and confident localization of the targets of focal somatic copy-number alteration in human cancers. Genome Biol. 2011;12(4):R41.

11. Li B, Dewey CN. RSEM: accurate transcript quantification from RNA-Seq data with or without a reference genome. BMC Bioinform. 2011;12:323.

12. Vivian J, et al. Toil enables reproducible, open source, big biomedical data analyses. Nat Biotechnol. 2017;35(4):314-6.

13. Eijkelenboom A, et al. Recommendations for the clinical interpretation and reporting of copy number gains using gene panel NGS analysis in routine diagnostics. Virchows Arch. 2019;474:673-80.

\section{Publisher's Note}

Springer Nature remains neutral with regard to jurisdictional claims in published maps and institutional affiliations.

Ready to submit your research? Choose BMC and benefit from:

- fast, convenient online submission

- thorough peer review by experienced researchers in your field

- rapid publication on acceptance

- support for research data, including large and complex data types

- gold Open Access which fosters wider collaboration and increased citations

- maximum visibility for your research: over $100 \mathrm{M}$ website views per year

At BMC, research is always in progress.

Learn more biomedcentral.com/submissions 